\title{
Viral myocarditis vs lupus myocarditis, distinctive features in Cardiovascular Magnetic Resonance
}

\author{
Maria A Espinoza Barillas \\ From 19th Annual SCMR Scientific Sessions \\ Los Angeles, CA, USA. 27-30 January 2016
}

\section{Background}

Myocardial inflammation may have multiple etiologies; infectious, toxic, and autoimmune. Acute cases are mostly due to myocardial involucre of a systemic viral infection. Although infectious myocarditis is routine in clinical practice for cardiologists, myocarditis presented by autoimmune diseases such as systemic lupus erythematosus also should be considered.

\section{Methods}

RMC was performed in 59 patients with suspected myocarditis: 30 patients with diagnosis of SLE based on the criteria of the American College of Rheumatology and symptoms and signs of lupus activity evidenced by ECLAM (European Consensus Lupus Activity Measurement) scale with or without cardiovascular symptoms, we excluded patients with SLE and recent intake of drugs or other substances associated with myocarditis,renal function failed and history of ischemic heart disease; And 29 patients that were assessed by certified cardiologists who suspected viral myocarditis due to the combination of the following factors: symptoms (chest pain, dyspnea and malaise), previously healthy and with no history of cardiovascular disease, with or without history of infection (upper respiratory tract infection and / or gastroenteritis) in the last 4 weeks. patients with coronary angiotomography and / or angiography for positive for atherosclerotic significant disease and patients with positive myocardial ischemia test.

\section{Results}

The most common clinical presentation in patients with lupus was dyspnea (83\%), in patients with viral myocarditis the symptom was chest pain (72\%) of them $62 \%$ had a history of a recent viral illness. In lupus myocarditis there

\footnotetext{
Radiology, Instituto Nacional De Ciencias Medicas Y Nutricion Salvador
} Zubiran, Mexico DF, Nicaragua 
less than half of patients with viral myocarditis (41\%). The location of these lesions had a similar behavior in both etiologies, anterior and inferoseptal being the most affected segments.

\section{Conclusions}

Lupus myocarditis unlike viral myocarditis, characteristically presents pancarditis with pericardial and valvular involvement, and most often affected the ventricular function. The late enhancement was the criteria that prevailed in lupus myocarditis. There were no differences in the location of delayed enhancement lesions between the two etiologies.

Published: 27 January 2016

doi:10.1186/1532-429X-18-S1-097

Cite this article as: Barillas: Viral myocarditis vs lupus myocarditis,

distinctive features in Cardiovascular Magnetic Resonance. Journal of

Cardiovascular Magnetic Resonance 2016 18(Suppl 1):097.

Submit your next manuscript to BioMed Central and take full advantage of:

- Convenient online submission

- Thorough peer review

- No space constraints or color figure charges

- Immediate publication on acceptance

- Inclusion in PubMed, CAS, Scopus and Google Scholar

- Research which is freely available for redistribution

Submit your manuscript at www.biomedcentral.com/submit
C Biomed Central 